These observations, all from within 50 miles of Flin Flon, from 1943 to 1971 , show that summer flocking is of fairly regular occurrence, at least in this area.

Reports of summer flocking of loons on lakes south of Kenora in western Ontario show that the phenomenon is not limited to the Flin Flon region. Robert $R$. Taylor (pers. commun., 1971) observed a flock of 16 at Dogtooth Lake, June 5, 1971, and an estimated 120 strung out in groups of 15 to 20 for three miles on Dryberry Lake, from 5:00 - 6:00 p.m., June 12, 1971. On August 4, 1970, he recorded two flocks of 21 birds each, about one-quarter mile apart on Hillock Lake.

That cooperative group feeding may occur even late in the season is suggested by an observation by Kip Park and Bob DeCruyenaere (pers. commun., October, 1971). An estimated 35 loons were seen fishing in a fairly tight flock occupying a circle of about 200 feet in diameter. When approached by boat, individuals dived when it was about 15 feet away, surfacing almost immediately once it moved out of that range. The boat moved well within the flock, which showed no indication of fear, nor made any attempt to fly off. This was at $3: 30$ p.m. on October 17, 1971, at Shoal Lake, just over the Manitoba border in western Ontario. The lake supports a fairly substantial loon population during the year.

Little information is available on fall migration and it is generally supposed, as reported by Chapman, that "loons move singly or in small groups at considerable height" (in Olson and Marshall, 1952: 69). Palmer (1962: 26-27) notes that "up to 300 birds may gather temporarily on small lakes when migrants encounter adverse weather." Campbell (1970) reported an unusually large number of loons migrating over Mille Lacs Lake in central eastern Minnesota early in the morning of November 11, 1969: "Very conservatively, I would estimate that at least 500 loons passed through my viewing area between $7 \mathrm{a} . \mathrm{m}$. and $9 \mathrm{a} . \mathrm{m}$. of that day. It seems that Mille Lacs is an important link in the migration route of the loons. I suppose this might be because of an abundance of fish like tullibees, central location, and the fact it freezes later than most other lakes."

\section{LITERATURE CITED}

Campbell, T. R. 1970. Loon concentration on Mille Lacs Lake. Loon, $42: 36$.

Olson, S. T., and W. H. Marshall. 1952. The Common Loon in Minnesota. Minn. Museum of Natural History, Occasional Papers No. 5, Univ. Minn. Press. 77 p.

Palmer, R. S. (Ed.) 1962. Handbook of North American birds. Vol. 1, Yale Univ. Press, New Haven. 567 p.

Rand, A. L. 1948. Summer flocking of the loon. Can. field-Nat., $62: 42-43$.

Wade, D. E., and D. R. Wade. 1963. Large concentration of Common Loons on Wildnest Lake. Blue Jay, 21:138.

\title{
GREAT CRESTED FLYCATCHER AGAIN OBSERVED IN ALBERTA
}

\section{by Graeme M. Greenlee, 10609 - 85 Ave., Edmonton 60}

The evening of June 19, 1971 was clear, calm and warm. My wife and I had driven to a location about nine miles east of Two Hills, Alberta. The site was stop number one of the Breeding Bird Survey which we were going to conduct the following morning. The topography was rolling and the countryside was covered with aspen, broken by scattered small clearing's seeded to tame hay.
The time was about 7:00 p.m. and we were standing beside the car, listening for bird calls. We heard two birds, one on either side of the road, uttering the same call. It was a call neither of us recognized, and could be described as a loud hoarse "cheep." As we began to move toward the source of the nearest call, a bird flew across the road in front of us. We did not immediately recognize it, but 
our first thought was: "western kingbird." It was about the same size as a Western Kingbird, had a dark back and yellow belly and flew like a flycatcher. Upon closer observation of the bird in a perched position, it was seen to have a flycatcher profile. However, the call was completely unlike any I have ever heard from a Western Kingbird, a bird with which J am completely familiar.

We followed and observed the two birds with $7 \times 50$ binoculars for about three-quarters of an hour, and had several good close looks at them. They had dark backs, gray throats (white in Western Kingbird), two white wing bars per wing (absent in Western Kingbird), long rusty tails (black with white outer tail feathers in Western Kingbird) and yellow bellies. In consultation with the field guide, Birds of North America by Robbins, Brunn, Zim and Singer, which we had with us, we identified these birds as Great Crested Flycatchers.

We could hardly believe our eyes, since these birds were not even on the hypothetical list in the first edition of Birds of Alberta by Salt and Wilk. (They are on the hypothetical list in the latest edition of the book, since Edgar T. Jones of Edmonton saw a pair about 30 miles east of the city a few years ago.) There was no doubt in our minds that they were Great Crested Flycatchers.

While we observed the two birds, their call was given repeatedly, often with a short trill on the end of it.

When we began our Breeding Bird
Survey the following morning at $3: 26$ a.m. the birds were again heard calling at the same spot. I returned to the same place at $4: 45$ a.m. on June 22 and stayed for an hour without hearing or seeing any sign of the birds. It was a calm morning with an overcast sky and cattle were bellowing and making a lot of noise in the area. I returned at $4: 30$ a.m. on a sunny calm June 29 and again heard the birds calling. I wandered through the woods for two hours searching for a nest, but was unsuccessful.

On June 30 , a sunny calm morning, I watched both birds between 5:00 and 5:30 a.m., but still found no nest. Two more Great Crested Flycatchers were heard calling and were seen between $6: 00$ and $6: 30$ a.m. on the same morning, three miles west of the original location. They could have been the same birds. On this occasion I noted that the call was given singly, or repeated several times in succession.

I did not again return to the area until $4: 45$ a.m. on July 7. It was a cloudy, windy, cool morning, and no Great Crested Flycatchers were heard or seen. I arrived at $4: 40$ the following day on a sunny, calm, cool morning, and heard and saw one of them. I spent two hours searching for a nest, but again was unsuccessful.

I heard and saw two again one mile east of the original location at 8:30 a.m., July 15 , and saw one at 8:00 a.m. the following morning in this same area.

I did not observe the birds again in 1971 but I was absent from the area between July 15 and August 26.

\section{A RARE OBSERVATION OF THE ESKIMO CURLEW}

\section{by Fred W. Lahrman, Saskatchewan Museum of Natural History, Regina}

On January 21,1972 , while on vacation in Texas, Dr. Fred G. Bard and I observed a bird which we are convinced was an Eskimo Curlew. The bird was sighted at about 11:40 a.m. on Padre Island, where we were watching birds at a location approximately one-half mile northeast of the end of the causeway connecting the island to the mainland at Port Isabel. 